\title{
The Indian Economy: \\ Current Performance and Short-Term Prospects
}

\author{
Raghbendra Jha
}

August 2007

\begin{abstract}
This paper provides an update on the historical and recent performance of the Indian economy. It reviews India's growth performance, and the supporting performance of savings and investment, productivity and international trade. It highlights the performance of a dynamic sector (automobiles) and a laggard sector (agriculture) and comments on the structure of income growth in recent times. It also points out emerging constraints on rapid economic growth, e.g., increasing regional and personal inequality, rising unemployment, infrastructural constraints and the fiscal deficit. It assesses the prospects for economic growth in the near term.
\end{abstract}

All correspondence to:

Prof. Raghbendra Jha,

Australia South Asia Research Centre,

Research School of Pacific and Asian Studies,

Australian National University,

Canberra, ACT 0200, Australia

Fax: + 61261250443

Email: r.jha@anu.edu.au 


\section{Introduction}

The political economy of India's economic growth is an issue of abiding interest. Higher and sustained economic growth has, all over the world, been the surest and most time tested means of raising living standards and reducing poverty. Further, given that it is a functioning democracy, economic policy in India can often be dictated by political expediency as political parties indulge in competitive populism in the face of improvements in social indicators such as literacy, infant mortality and the like lagging behind rises in the rate of economic growth. Thus the political economy of policy formulation is an important area of concern. Finally, an analysis of what policies can be undertaken given these constraints is an important indicator of potential welfare implications of policies for such a large section of humanity.

Several recent reviews of India's recent growth experience exist (Rodrik and Subrahmanian, 2004, Kelkar, 2004, and Thirlwell, 2004 are three examples). The value added of the present paper is to place India's growth experience within a broader political economy perspective. It documents the broad contours of economic growth in India (section II) and then describes the increase in resources available (in the forms of higher saving and investment and lower fiscal deficit) for higher economic growth in section III. It examines the recent surge in the external engagement of the Indian economy in section IV whereas section V contrasts the recent performance of a rapidly growing sector (automobiles) with a laggard sector (agriculture). Section VI examines some emerging constraints to rapid economic growth in India whereas section VII evaluates the prospects for alleviating these constraints. Section VIII concludes.

\section{The Record of Economic Growth in India}

By all accounts from the $15^{\text {th }}$ to the $18^{\text {th }}$ century India was one of the most prosperous regions of the world with plentiful supply of highly advanced commercial and industrial techniques (Clydesdale 2007). From 1700, however, Indian GDP per capita started to drop. For more than 400 years now India has had low incomes and low, even negative, rates of economic growth whereas its population has continued to expand. Table 1 compares real per capita GDP and GDP in 1990 international dollars and population between India and the United Kingdom over the period 1600 to 1947, when India attained independence from British rule.

Table 1: Comparative Macroeconomic Performance of India and Britain, 1600-1947

\begin{tabular}{|c|c|c|c|c|c|}
\hline & 1600 & 1700 & 1757 & 1857 & 1947 \\
\hline & \multicolumn{5}{|c|}{ Per Capita GDP (1990 international dollars) } \\
\hline India & 550 & 550 & 540 & 520 & 618 \\
\hline \multirow[t]{2}{*}{ United Kingdom } & 974 & 1250 & 1424 & 2717 & 6361 \\
\hline & \multicolumn{5}{|c|}{ Population (000) } \\
\hline India & 135000 & 165000 & 185000 & 227000 & 414000 \\
\hline \multirow[t]{2}{*}{ United Kingdom } & 6170 & 8565 & 13180 & 28187 & 49519 \\
\hline & \multicolumn{5}{|c|}{ GDP (million 1990 international dollars) } \\
\hline India & 74250 & 90750 & 99900 & 118040 & 255852 \\
\hline United Kingdom & 6007 & 10709 & 18768 & 76584 & 314969 \\
\hline
\end{tabular}

Source: Maddison (2006). 
India's per capita GDP which in 1600 was 56.4 percent of the UK's, remained stagnant and even fell for a while during the period until 1947 at which time UK's per capita GDP was 10.3 times that of India. The ratio of UK's per capita GDP to Indian GDP grew from 2.63 in 1757 (an approximate date for the beginning of British rule in India) to 5.22 in 1857 and 10.29 in 1947. Over the same period the ratio of India's population to British population fell from 14.03 in 1757 to 8.05 in 1857 and rose only marginally to 8.36 in 1947 . The ratio of British GDP to Indian GDP was 0.187 in 1757, but rose to 0.648 in 1857 and 1.23 in 1847. Thus in 1947 British GDP surpassed India’s.

However, India's colonial experience was not unique since most colonies that did not result in settlements had poor records of economic growth, even stagnation (Tables 2 and 3). Table 2 shows levels of GDP per capita in the major European colonial powers and some colonies for about 500 years. Table 3 provides information on growth rates in the same countries.

Table 2: Levels of GDP per capita in European Colonial Powers and Former Colonies, 15001998 (1990 international dollars)

\begin{tabular}{|l|c|r|r|r|r|r|}
\hline & 1500 & 1700 & 1820 & 1913 & 1950 & 1998 \\
\hline & \multicolumn{5}{|l|}{} \\
\hline Britain & 762 & 1405 & 2121 & 5150 & 6907 & 18714 \\
\hline France & 727 & 986 & 1230 & 3485 & 5270 & 19558 \\
\hline Italy & 1100 & 1100 & 1117 & 2564 & 3502 & 17759 \\
\hline Netherlands & 754 & 2110 & 1821 & 4049 & 5996 & 20224 \\
\hline Portugal & 632 & 854 & 963 & 1244 & 2069 & 12929 \\
\hline Spain & 698 & 900 & 1063 & 2255 & 2397 & 14227 \\
\hline & Former Colonial Powers & & \\
\hline China & 600 & 600 & 600 & 552 & 439 & 3117 \\
\hline India & 550 & 550 & 533 & 673 & 619 & 1746 \\
\hline Indonesia & 565 & 580 & 612 & 904 & 840 & 3070 \\
\hline Brazil & 400 & 460 & 646 & 811 & 1672 & 5459 \\
\hline Mexico & 425 & 568 & 759 & 1732 & 2365 & 6655 \\
\hline United States & 526 & 715 & 880 & 2736 & 3446 & 18183 \\
\hline
\end{tabular}

Source: Maddison (2006).

Whereas the European colonial powers and the settlement countries, e.g., the US, recorded positive rates of growth of per capita GDP, period growth rates in the colonies were stagnant, if not negative, before their respective independence. ${ }^{1}$

\footnotetext{
${ }^{1}$ In an important work Nurkse (1953) emphasized the difference between the settlement and non settlement countries among the set of colonized countries as involving the method of financing of capital. Whereas the bulk of investment in settlement countries was through equity the non-settlement countries received loans, which they had to service. This debt servicing put onerous burdens on the already fragile economies of the non-settlement colonized countries (Maddison 2006).
} 
Table 3: Growth of per capita GDP in European Colonial Powers and Former Colonies, 15001998 (annual average compound growth rates)

\begin{tabular}{|l|c|c|c|c|c|}
\hline & $1500-1700$ & $1700-1820$ & $1820-1913$ & $1913-1950$ & $1950-1998$ \\
\hline & \multicolumn{5}{|l|}{ European Colonial Powers } \\
\hline Britain & 0.31 & 0.34 & 0.96 & 0.80 & 2.10 \\
\hline France & 0.15 & 0.18 & 1.13 & 1.12 & 2.77 \\
\hline Italy & 0.00 & 0.01 & 0.90 & 0.85 & 3.44 \\
\hline Netherlands & 0.52 & -0.12 & 0.86 & 1.07 & 2.56 \\
\hline Portugal & 0.15 & 0.10 & 0.27 & 1.38 & 3.89 \\
\hline Spain & 0.13 & 0.14 & 0.81 & 0.17 & 3.78 \\
\hline & Former Colonies & & & & \\
\hline China & 0.00 & 0.00 & -0.08 & -0.62 & 4.17 \\
\hline India & 0.00 & -0.03 & 0.25 & -0.23 & 2.18 \\
\hline Indonesia & 0.01 & 0.04 & 0.42 & -0.20 & 2.74 \\
\hline Brazil & 0.07 & 0.28 & 0.89 & 0.85 & 2.18 \\
\hline Mexico & 0.15 & 0.24 & 0.89 & 0.85 & 2.18 \\
\hline United States & 0.14 & 0.73 & 1.56 & 1.61 & 2.21 \\
\hline Ireland & 0.15 & 0.17 & 1.23 & 0.63 & 3.53 \\
\hline
\end{tabular}

Source: Maddison (2006).

Thus the colonial experience was impoverishing for several colonies. In India itself the effects went beyond the purely economic as the following quote from the Nobel laureate poet Rabindranath Tagore reveals:

Rudely shaken out of my dream I began to realize that perhaps in no other modern state was there such hopeless dearth of the most elementary needs of existence. And all the time before our eyes Japan has been transforming herself into a mighty and prosperous nation. I have also been privileged to witness the unsparing energy with which Russia has succeeded in steadily liquidating ignorance and poverty wiping off the humiliation from the face of a vast continent. I cannot help contrasting two systems of governance: one based on cooperation and the other on exploitation. Thus, while these other countries were marching ahead, India smothered under the dead weight of British administration lay static in her utter helplessness. (Tagore 1941, p. 637)

Table 2 reveals that despite India's dismal economic performance for 350 years India's GDP per capita in 1950 was higher than China's. Currently China's GDP per capita is higher than India's by a factor of almost 3 indicating that since independence India's advantage over China has disappeared. India's post independence growth did not have an auspicious start, although growth has accelerated considerably of late. It is thus pertinent to examine India's growth experience in the post independence era in some detail.

The record of economic growth (annual rate of growth of real GNP) in independent India has been uneven. Until about 1980 growth rates were low and subject to considerable volatility. This record has improved since then. In Table 4 I depict salient characteristics of aggregate economic growth in India. 
Table 4: Some Basic Characteristics of Growth of Real GNP in India

\begin{tabular}{|l|c|c|}
\hline \multicolumn{1}{|c|}{ Period } & $\begin{array}{c}\text { Mean Annual Growth Rate } \\
\text { (percentages) }\end{array}$ & $\begin{array}{c}\text { Standard Deviation of Year to Year Growth Rate } \\
\text { (percentages) }\end{array}$ \\
\hline $1951-52$ to $1959-60$ & 3.58 & 2.62 \\
\hline $1960-61$ to $1969-70$ & 3.91 & 3.64 \\
\hline $1970-71$ to $1979-80$ & 3.05 & 4.16 \\
\hline $1980-81$ to $1989-90$ & 5.65 & 2.27 \\
\hline $1990-91$ to $1999-00$ & 5.83 & 1.97 \\
\hline $1992-93$ to $1999-00$ & 6.46 & 1.16 \\
\hline $2001-02$ to $2005-06^{\text {a }}$ & 6.82 & 1.99 \\
\hline $\begin{array}{l}2001-02 \text { to } 2005-06 \\
(2002-03 \text { excluded) }\end{array}$ & 7.55 & 1.2 \\
\hline
\end{tabular}

N.B. (a) 2002-03 was a significant drought year and its inclusion raised the standard deviation of the growth rate. If 2002-03 is excluded the average growth for 2001-02 to 2005-06 would have been $7.55 \%$ and the standard deviation 1.2.

Source: Author's calculation based on data from Reserve Bank of India Handbook of Statistics on the Indian Economy

In aggregate terms growth appears to have picked up significantly since the 1980s. Further, the variability of this growth (as measured by the standard deviation) has come down significantly. Per capita GDP growth which was 1.2 percent per annum during 1972-82, accelerated to 3.0 percent during 1982-92 and further to 3.9 percent during 1992-2002. In recent times it has accelerated even further. So the Indian economy has been enjoying high and relatively stable rates of growth for more than a quarter century now. Recent experience of economic growth (and its sectoral composition) is shown in Table 5 and Figure 1.

Table 5: Growth Rates of Real GDP (per cent)

\begin{tabular}{|c|c|c|c|c|c|}
\hline Sector & $\begin{array}{c}1993-94 \text { to } \\
2002-03 \\
\text { (average) }\end{array}$ & $\begin{array}{c}2000-01 \text { to } \\
2006-07 \\
\text { (average) }\end{array}$ & 2004-05 & $2005-06$ & 2006-07 \\
\hline 1. Agriculture and Allied Activities & $\begin{array}{c}2.1 \\
(26.5)\end{array}$ & 2.5 & $\begin{array}{c}0.0 \\
(20.2)\end{array}$ & $\begin{array}{c}6.0 \\
(19.7)\end{array}$ & $\begin{array}{c}2.7 \\
(18.5)\end{array}$ \\
\hline 1.1 Agriculture & 2.0 & & & & \\
\hline 2. Industry & $\begin{array}{c}6.6 \\
(22.1)\end{array}$ & 7.0 & $\begin{array}{c}8.4 \\
(19.6)\end{array}$ & $\begin{array}{c}8.0 \\
(19.4)\end{array}$ & $\begin{array}{c}11.0 \\
(19.7)\end{array}$ \\
\hline 2.1 Mining and Quarrying & 4.7 & 4.6 & 7.5 & 3.6 & 5.1 \\
\hline 2.2 Manufacturing & 7.1 & 7.7 & 8.7 & 9.1 & 12.3 \\
\hline 2.3 Electricity, Gas and Water supply & 5.2 & 4.8 & 7.5 & 5.3 & 7.4 \\
\hline 3. Services & $\begin{array}{c}7.8 \\
(51.4)\end{array}$ & 8.6 & $\begin{array}{c}10.0 \\
(60.2)\end{array}$ & $\begin{array}{c}10.3 \\
(60.9)\end{array}$ & $\begin{array}{c}11.0 \\
(61.8)\end{array}$ \\
\hline $\begin{array}{l}\text { 3.1 Trade, Hotels, Restaurants, Transport, } \\
\text { Storage and Communication }\end{array}$ & 8.8 & 10.3 & 10.9 & 10.4 & 13.0 \\
\hline $\begin{array}{l}\text { 3.2 Financing, Insurance, Real Estate and } \\
\text { Business Services }\end{array}$ & 8.0 & 7.9 & 8.7 & 10.9 & 10.6 \\
\hline $\begin{array}{l}\text { 3.3 Community, Social and Personal } \\
\text { Services }\end{array}$ & 6.9 & 6.0 & 7.9 & 7.7 & 7.8 \\
\hline 3.4 Construction & 5.7 & 9.9 & 14.1 & 14.2 & 10.7 \\
\hline 4. Real GDP at Factor Cost & $\begin{array}{l}6.0 \\
(100)\end{array}$ & $\begin{array}{l}6.9 \\
(100)\end{array}$ & $\begin{array}{l}7.5 \\
(100)\end{array}$ & $\begin{array}{l}9.0 \\
(100)\end{array}$ & $\begin{array}{l}9.4 \\
(100)\end{array}$ \\
\hline
\end{tabular}

Note: Figures in parentheses denote shares in real GDP.

Source: Reserve Bank of India. 
Table 5 displays broad averages of sectoral growth rates as well as the significance of these sectors measured by their shares in GDP. At the sectoral level agricultural growth has continued to fluctuate considerably even as the share of agriculture in GDP has come down sharply. ${ }^{2}$ Manufacturing sector growth rates have not been particularly high, until recently, and the share of industry in GDP has been stagnant at about 22 per cent. Manufacturing growth was high in the initial years of the post reforms period but fell sharply in 2001-02. The subsequent pick-up in 2002-03 was probably because of the lower base in 2001-02. However, industrial growth rates have since been robust and have become comparable to growth rate of services. Growth in mining has been less spectacular. Growth in electricity production has been slow - perhaps reflecting the poor state of electricity generation and, particularly, transmission and distribution in India. The highest growth sector has been services. Growth in this sector has occurred across a broad range and has been the most stable of all sectoral growth rates. As a consequence, the share of services in GDP has gone up substantially.

The evolution over time of the sectoral composition of Indian GDP is portrayed in Figure 1.

Figure 1: Sectoral Composition of India's GDP

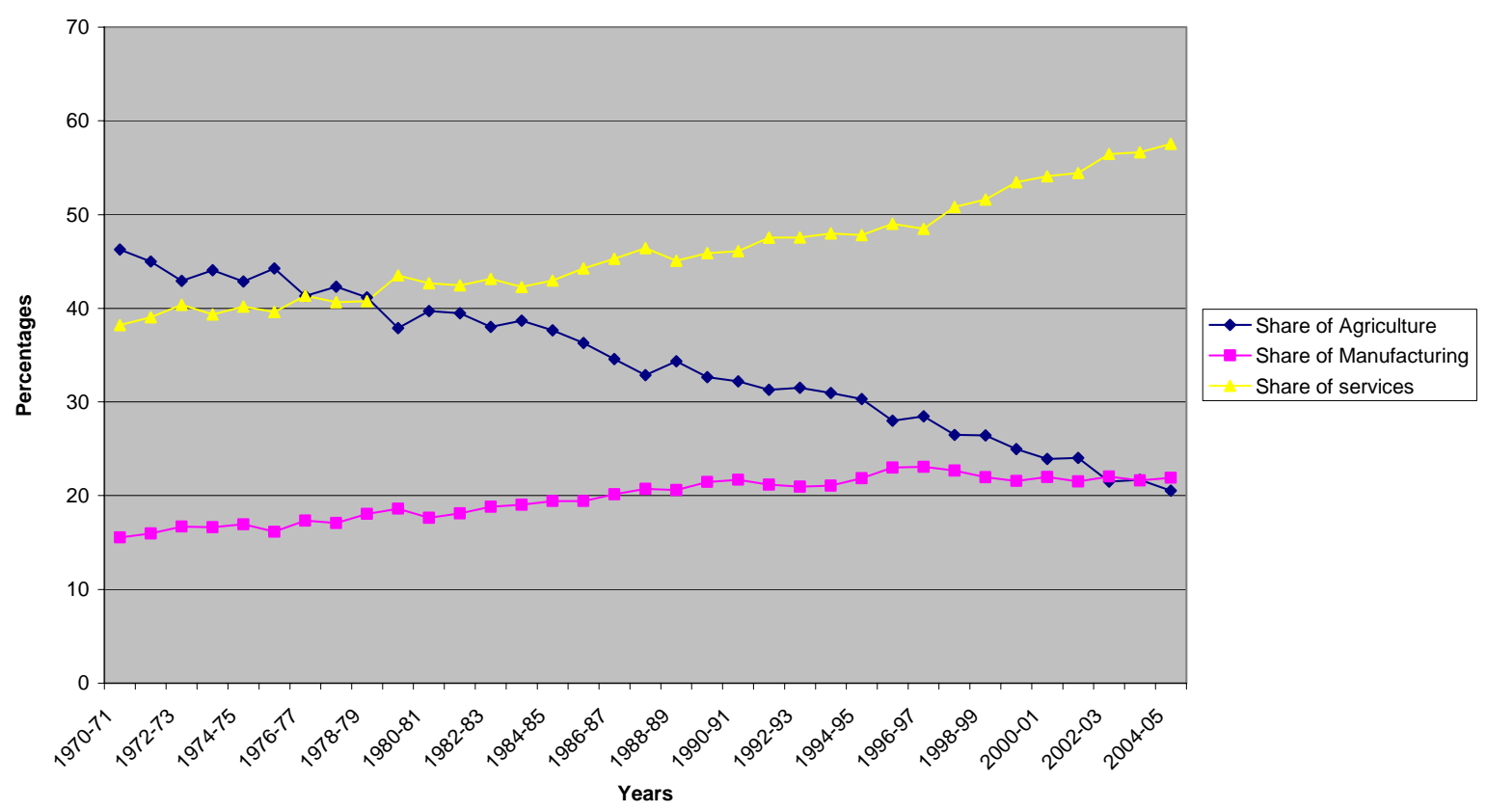

Source: Based on data from Handbook of Indian Statistics (2006), Reserve Bank of India.

Real GDP growth was at 9.0 per cent in 2005-06 and accelerated to 9.4 per cent in 2006-07. This comes on the back of two good years for GDP growth: 8.5 per cent in 2003-04 and 7.5 per cent in 2004-05. As a consequence of such rapid growth India is now a huge market with a large and young population. As much as 95.1 per cent of India's billion plus population is below the age of 65 , with almost a third being younger than 14 . A Reuters report estimates that by the time these children enter the labour force India will be a US $\$ 1$ trillion plus (at market exchange rates) economy. By some reckoning India's middle class (those earning between US\$2000 to $\$ 22,000$ a year) is 300 million strong. More importantly this young

\footnotetext{
2 The share of agriculture in employment is, however, much higher. One of the current important anomalies in the Indian economy is that a sector that produces 25 per cent of GDP employs 65 per cent of the labour force.
} 
labour force is keen to enrich itself quickly and to compete with the outside world - witness India's persistent double-digit export growth in recent years. Furthermore, India's growth is likely to be less dependent on global growth than other Asian countries since it does not rely excessively on manufacturing exports. The service sector accounts for more than 31 per cent of India's exports. Thus any downturn in the global economy may have less impact on India.

One concern attending recent economic growth in India is that since it has been demand led and faces key infrastructural constraints, inflation has picked up. In particular, CPI-AL (the price index most relevant for the poor in India) has risen more rapidly than the wholesale price index or the CPI-IW. The RBI has raised the cost of borrowing successively to rein in inflation. This move seems to be having the desired effect although much will depend on the South West monsoons and the supply situation thereafter. In a recent report the World Bank has opined that this may reduce growth in the near term, but this does not factor in policy responses of the government.

\section{Factors Accelerating Economic Growth in India}

The current high rate of economic growth could well accelerate further as Kelkar (2004) has opined. Contributing to this acceleration is a broad series of reforms including financial sector reforms, increased globalization and widening and deepening of product and financial markets. The impact of such reforms gets reflected in key indicators such as market capitalization of the stock market, the technology and transparency of transactions, the sets of instruments traded, balance sheets of financial institutions and the degree of openness of the economy. At the same time a benign FDI policy framework has permitted greater tie-ups in high technology areas for production for domestic as well as external markets. I now comment on some factors responsible, in a growth accounting sense, for the acceleration in economic growth.

\section{Productivity Growth}

The higher GDP growth rate beginning in the 1980s has been accompanied by an even sharper acceleration in total factor productivity growth. Rodrik and Subramanian (2004) examine a number of possible explanations for this rise in productivity/growth. Such explanations include Keynesian type demand-led expansion in the 1980s, the advent of the Green Revolution, and possible external and internal liberalization. However, they find empirical support for attitudinal changes in the governments of Indira and later, Rajiv Gandhi. These administrations, it is argued, began viewing private investment and enterprise more favorably and modest reforms were initiated. This had salutary effects on manufacturing sector productivity and later had substantial spillover effects. As a result, the rate of growth of the economy picked up. Such beneficial synergies were helped by the climate of deregulation and delicensing started in the early 1990s. Other authors have placed a much stronger emphasis on the role of the post 1991 reforms and downplayed the role of policy initiatives of the 1980s. ${ }^{3}$ To be sure, financial sector reforms began only in 1993 and are yet to be completed. ${ }^{4}$

\footnotetext{
${ }^{3}$ There has been a debate of sorts about whether attitudinal changes in the government bureaucracy or actual policy changes are better explanations for the acceleration in economic growth in India. In a country with an autarkic trade regime and a highly centralized administrative structure, attitudinal changes may well be the hardest to make. Hence, both policy measures as well as attitudinal changes should be regarded as essential as well as complementary explanations for this surge in the rate of growth.

${ }^{4}$ For a review of financial sector reforms in India see Sharma (2004).
} 
Table 6 documents the acceleration in total factor productivity growth in India.

Table 6: Sources of Growth in India: Aggregate and by Major sectors (percent per year)

\begin{tabular}{|c|c|c|c|c|c|c|c|}
\hline \multicolumn{8}{|c|}{ Aggregate Economy } \\
\hline & & & & \multicolumn{4}{|c|}{ Contribution of } \\
\hline Period & Output & Employment & $\begin{array}{c}\text { Output per } \\
\text { worker }\end{array}$ & $\begin{array}{c}\text { Physical } \\
\text { capital }\end{array}$ & Land & Education & $\begin{array}{c}\text { Factor } \\
\text { productivity }\end{array}$ \\
\hline 1978-04 & 5.4 & 2.0 & 3.3 & 1.3 & 0.0 & 0.4 & 1.6 \\
\hline $1978-93$ & 4.5 & 2.1 & 2.4 & 1.0 & -0.1 & 0.3 & 1.1 \\
\hline 1993-04 & 6.5 & 1.9 & 4.6 & 1.8 & 0.0 & 0.4 & 2.3 \\
\hline \multicolumn{8}{|c|}{ Agriculture } \\
\hline 1978-04 & 2.5 & 1.1 & 1.4 & 0.4 & -0.1 & 0.3 & 0.8 \\
\hline $1978-93$ & 2.7 & 1.4 & 1.3 & 0.2 & -0.1 & 0.2 & 1.0 \\
\hline 1993-04 & 2.2 & 0.7 & 1.5 & 0.7 & -0.1 & 0.3 & 0.5 \\
\hline \multicolumn{8}{|l|}{ Industry } \\
\hline 1978-04 & 5.9 & 3.4 & 2.5 & 1.5 & & 0.3 & 0.6 \\
\hline $1978-93$ & 5.4 & 3.3 & 2.1 & 1.4 & & 0.4 & 0.3 \\
\hline 1993-04 & 6.7 & 3.6 & 3.1 & 1.7 & & 0.3 & 1.1 \\
\hline \multicolumn{8}{|l|}{ Services } \\
\hline 1978-04 & 7.2 & 3.8 & 3.5 & 0.6 & & 0.4 & 2.4 \\
\hline $1978-93$ & 5.9 & 3.8 & 2.1 & 0.3 & & 0.4 & 1.4 \\
\hline 1993-04 & 9.1 & 3.7 & 5.4 & 1.1 & & 0.4 & 3.9 \\
\hline
\end{tabular}

Source: Bosworth and Collins (2007)

\section{Improvements in Labour Supply}

Adding to the impetus for higher economic growth are certain structural changes occurring in the Indian economy - particularly on the supply side. In 2000 the proportion of the Indian population in the working age group (15-64 age bracket) was $60.9 \%$. The UN's Population Division has projected that this ratio will surpass the proportion of Japanese in this age group by 2012 and climb to over 66\% in 30 years. At that point in time it is poised to overtake China's population in the same age group. This is a very significant projection.

At the same time a quiet revolution is taking place in nutritional status in India with calorie and other macro and micro nutrient deficiency on the decline. . Further, during the period 1991 to 2001 the literacy rate climbed from $51.54 \%$ to $65.38 \%$ in the aggregate, from 63.3 $\%$ to $75.85 \%$ for males and from 38.79 to $54.16 \%$ for females, according to figures of the 2001 Census of India. Thus India's labour force is younger, better nourished and has more skills than before. Clearly India's labour force is undergoing rapid structural transformation: the proportion of the working population is rising; the labour force is less nutritionally deprived and increasingly literate. These changes imply substantial quality improvements in the Indian labour force. Economic theory and international experience leads us to believe that this will lead to sharp rises in labour productivity and an upward shift in the trend long run rate of growth of the Indian economy. 


\section{Higher Savings for Enhanced Economic Growth}

Central to the growth success story has been a steady rise in India's saving and investment rates as Table 7 indicates.

\section{Table 7: Savings and Investment in India}

\begin{tabular}{|c|c|c|c|c|c|c|c|}
\hline \multicolumn{8}{|c|}{ Savings and Investment (Base: 1999-2000) as per cent of GDP at Current Market Prices } \\
\hline & 1999-00 & 2000-01 & $2001-02$ & $2002-03$ & 2003-04 & 2004-05 & \begin{tabular}{|l}
$2005-06$ \\
(estimated)
\end{tabular} \\
\hline Gross Domestic Savings, of which & 24.8 & 23.4 & 23.5 & 26.4 & 29.7 & 31.1 & 32.4 \\
\hline a) Public & -0.8 & -1.9 & -2.0 & -0.6 & 1.2 & 2.4 & 2.0 \\
\hline b) Private, of which & 25.6 & 25.3 & 25.5 & 27.0 & 28.5 & 28.7 & 30.4 \\
\hline i) Household, of which & 21.1 & 21.0 & 21.8 & 22.7 & 23.8 & 21.6 & 22.3 \\
\hline Financial & 10.6 & 10.2 & 10.8 & 10.3 & 11.3 & 10.2 & 11.7 \\
\hline Physical & 10.5 & 10.8 & 10.9 & 12.4 & 12.4 & 11.4 & 10.7 \\
\hline ii) Private corporate & 4.5 & 4.3 & 3.7 & 4.2 & 4.7 & 7.1 & 8.1 \\
\hline $\begin{array}{l}\text { Gross Domestic Investment, } \\
\text { of which }\end{array}$ & 25.9 & 24.0 & 22.9 & 25.2 & 28.0 & 31.5 & 33.8 \\
\hline Public & 7.4 & 6.9 & 6.9 & 6.1 & 6.3 & 7.1 & 7.4 \\
\hline Private & 17.9 & 16.5 & 16.3 & 18.4 & 19.4 & 21.3 & 23.6 \\
\hline Valuables & 0.8 & 0.7 & 0.6 & 0.6 & 0.9 & 1.3 & 1.2 \\
\hline $\begin{array}{l}\text { Gross Fixed Capital Formation, } \\
\text { of which }\end{array}$ & 23.4 & 22.8 & 23.0 & 23.8 & 24.8 & 26.3 & 28.1 \\
\hline Changes in stocks & 1.9 & 0.6 & 0.2 & 0.7 & 0.8 & 2.0 & 2.9 \\
\hline Valuables & 0.8 & 0.7 & 0.6 & 0.6 & 0.9 & 1.3 & 1.2 \\
\hline Saving - Investment & -1.1 & -0.6 & 0.6 & 1.2 & 1.6 & -0.4 & -1.3 \\
\hline Public & -8.2 & -8.8 & -8.9 & -6.6 & -5.2 & -4.7 & -5.4 \\
\hline Private & 7.7 & 8.8 & 9.2 & 8.6 & 9.2 & 7.4 & 6.9 \\
\hline
\end{tabular}

Source: Economic Survey, Government of India, 2006-07

Savings have risen from 23.4 per cent of GDP in 2000-01 to 32.4 per cent in 2005-06 whereas during the same period investment rose from 24 per cent of GDP to 33.8 per cent of GDP. Public sector saving turned positive in 2003-04 indicating improved tax and budgetary performance and the implementation of the Fiscal Reforms and Budget Management Act (FRBMA) in 2002-03. With 33.8 per cent investment in 2005-06 India was able to obtain 9 per cent GDP growth whereas China obtains 9 per cent growth with investment rates of over 40 per cent. Thus the productivity of capital is higher in India than in China.

As India seeks to accelerate its growth rate even further in order to reduce poverty and become a major player in the global economy, raising the saving and investment rates through lowering fiscal deficits will be key. India needs to streamline public subsidies and increase tax revenues in order to reduce, if not eliminate, public dissaving in order to boost economic growth. In recent times, particularly since the enactment of the FRBMA, India's fiscal deficit situation has improved as indicated in table 8. 
Table 8: India: Key Fiscal Indicators (per cent of GDP)

\begin{tabular}{|c|c|c|c|c|}
\hline Year & Primary Deficit & Revenue Deficit & Gross Fiscal Deficit & $\begin{array}{l}\text { Outstanding Liabilities } \\
\text { (including external } \\
\text { liabilities at historic } \\
\text { exchange rates) }\end{array}$ \\
\hline \multicolumn{5}{|l|}{ Centre } \\
\hline $2002-03$ & 1.1 & 4.4 & 5.9 & 63.4 \\
\hline 2003-04 & -0.03 & 3.6 & 4.5 & 62.8 \\
\hline 2004-05 & -0.04 & 2.5 & 4.0 & 63.8 \\
\hline $2005-06$ & 0.4 & 2.6 & 4.1 & 63.4 \\
\hline 2006-07 (RE) & 0.1 & 2.0 & 3.7 & 61.5 \\
\hline $2007-08$ (BE) & -0.2 & 1.5 & 3.3 & 59.2 \\
\hline \multicolumn{5}{|l|}{ States } \\
\hline $2002-03$ & 1.3 & 2.2 & 4.2 & 32.5 \\
\hline 2003-04 & 1.5 & 2.2 & 4.5 & 33.4 \\
\hline 2004-05 & 0.7 & 1.2 & 3.5 & 33.3 \\
\hline $2005-06$ & 0.1 & 0.04 & 2.4 & 32.5 \\
\hline 2006-07 (RE) & 0.4 & -0.01 & 2.6 & 30.3 \\
\hline 2007-08 (BE) & -0.02 & -0.4 & 2.1 & 29.2 \\
\hline \multicolumn{5}{|l|}{ Combined } \\
\hline $2002-03$ & 3.1 & 6.6 & 9.6 & 80.7 \\
\hline 2003-04 & 2.1 & 5.8 & 8.5 & 81.4 \\
\hline 2004-05 & 1.4 & 3.7 & 7.5 & 82.4 \\
\hline $2005-06$ & 1.0 & 2.6 & 6.6 & 80.5 \\
\hline 2006-07 (RE) & 0.7 & 2.0 & 6.2 & 77.0 \\
\hline 2007-08 (BE) & 0.0 & 1.2 & 5.3 & 74.2 \\
\hline
\end{tabular}

RE= Revised Estimates

$\mathrm{BE}=$ budget estimates

Source: Reserve Bank of India

Though fiscal deficits have been coming down successive reductions have become harder to achieve. It is not clear whether the FRBMA goal of achieving zero revenue deficit by 2009 will be achieved. In the meantime public debt is nearly 75 per cent of GDP. External debt is low, with a large share in long term debt. Hence pressures on the exchange rate because of high external debt are minimal. In addition India's foreign exchange rate reserves on 25 May 2007 stood at US $\$ 204.9$ billion, a substantial part of which comes from sterilisation operations to keep the exchange rate competitive for exporters.

\section{India's External Sector Performance}

Another notable aspect of the recent acceleration in India's economic growth has been its greater economic integration with the global economy. International trade reforms have proceeded rapidly in India. India missed the first phase of trade liberalization in the post-War period but is has not done so this time around. Indian manufacturing tariffs are now low by world developing country standards: $12.5 \%$ or below and Indian anti-dumping appears to be slowing down. India is far less dependent on tariffs for government revenue but agricultural tariff reduction has not kept pace with industrial tariff liberalization. A necessary but not sufficient condition for it to be reversed would be agricultural protection cuts in developed countries. As a consequence India's exports have surged and India's export basket is geared towards high value added items such as engineering goods (Tables 9-12). 
Table 9: Growth in Exports (per cent)

\begin{tabular}{|l|l|l|l|l|}
\hline Region/Country & 2004 & 2005 & 2006 & 2007 (Q1) \\
\hline World & 21.2 & 14.1 & 15.5 & 18.5 \\
\hline Industrial Countries & 17.3 & 8.5 & 12.6 & 12.9 \\
\hline USA & 12.9 & 10.8 & 9.7 & 9.4 \\
\hline Germany & 21.3 & 7.3 & 15.1 & 20.8 \\
\hline Japan & 19.9 & 5.2 & 9.2 & 5.4 \\
\hline Developing Countries & 27.3 & 22.1 & 19.2 & 25.8 \\
\hline China & 35.3 & 28.4 & 27.2 & 27.8 \\
\hline India & 28.2 & 29.6 & 21.5 & 12.6 \\
\hline Korea & 31.0 & 12.0 & 14.4 & 14.6 \\
\hline Singapore & 24.6 & 15.6 & 18.4 & 9.9 \\
\hline Malaysia & 26.5 & 12.0 & 14.0 & 7.6 \\
\hline Thailand & 19.8 & 14.5 & 18.7 & 17.2 \\
\hline
\end{tabular}

Source: IMF (International Financial Statistics) and RBI.

Table 10: Commodity Composition of India's Exports

\begin{tabular}{|l|l|l|l|l|l|l|}
\hline & \multicolumn{3}{l}{ Percentage Share } & \multicolumn{3}{l|}{ Growth Rate (in US \$ terms) } \\
\hline Commodity Group & $2004-05$ & $2005-06$ & $\begin{array}{l}2006-07 \\
\text { (April- } \\
\text { October) }\end{array}$ & $2004-05$ & $2005-06$ & $\begin{array}{l}\text { 2006-07 } \\
\text { (April-October) }\end{array}$ \\
\hline 1. Primary Products, of which & 16.0 & 15.4 & 13.9 & 36.2 & 18.9 & 17.3 \\
\hline Agriculture and allied & 10.5 & 10.2 & 9.9 & 11.7 & 19.8 & 25.4 \\
\hline Ores and Minerals & 5.5 & 5.2 & 4.0 & 136.5 & 17.4 & 1.1 \\
\hline $\begin{array}{l}\text { 2. Manufactured Goods, of } \\
\text { which }\end{array}$ & 74.2 & 72.0 & 69.0 & 24.9 & 19.6 & 17.6 \\
\hline Textiles incl. RMG & 14.9 & 14.5 & 9.8 & 5.3 & 20.4 & 11.7 \\
\hline Gems and Jewellery & 16.5 & 15.1 & 12.9 & 30.2 & 12.8 & -4.4 \\
\hline Engineering goods & 20.7 & 20.7 & 22.5 & 40.2 & 23.4 & 37.0 \\
\hline $\begin{array}{l}\text { Chemicals and related } \\
\text { products }\end{array}$ & 12.2 & 11.6 & 10.4 & 33.9 & 17.3 & 14.8 \\
\hline Leather and Manufactures & 2.9 & 2.6 & 1.8 & 12.0 & 11.1 & 5.7 \\
\hline $\begin{array}{l}\text { Handicrafts (incl. carpet } \\
\text { handmade) }\end{array}$ & 1.2 & 1.2 & 1.0 & -7.0 & 30.2 & -7.3 \\
\hline $\begin{array}{l}\text { 3. Petroleum, Crude and } \\
\text { products (incl. coal) }\end{array}$ & 8.5 & 11.5 & 16.3 & 91.2 & 66.2 & 85.3 \\
\hline Total exports & 100.0 & 100.0 & 100.0 & 30.8 & 23.4 & 25.3 \\
\hline
\end{tabular}

Source: Economic Survey Government of India 
Table 11: India’s Merchandise Trade

\begin{tabular}{|l|c|c|c|}
\hline & \multicolumn{3}{|c|}{ US \$ billion } \\
\hline & $2004-05$ & $2005-06$ & $2006-07$ (April to December) \\
\hline Exports & 83.5 & 103.1 & 89.5 \\
\hline Imports & 111.5 & 149.2 & 131.2 \\
\hline Oil & 29.8 & 44.0 & 43.8 \\
\hline Non-Oil & 81.7 & 105.2 & 87.4 \\
\hline Trade Balance & -27.9 & -46.1 & -41.6 \\
\hline Non-oil trade balance & -5.1 & -13.6 & $-6.3^{\star}$ \\
\hline & & Variation (per cent) & $2006-07$ (April to December) \\
\hline & $2004-05$ & $2005-06$ & 22.0 \\
\hline Exports & 30.8 & 23.4 & 24.8 \\
\hline Imports & 42.7 & 33.8 & 39.2 \\
\hline Oil & 45.1 & 47.3 & 18.7 \\
\hline Non-Oil & 41.8 & 28.8 & \\
\hline
\end{tabular}

* April-September. Source: RBI

Table 12: Invisibles Account (Net) US \$ million

\begin{tabular}{|l|c|c|}
\hline & $2005-06$ & 2006-07 (April - September) \\
\hline 1. Services, of which & 23881 & 14298 \\
\hline Travel & 1389 & 240 \\
\hline Transportation & -1550 & 55 \\
\hline Insurance & 22 & 273 \\
\hline Government, not included elsewhere & -197 & -86 \\
\hline Software & 22262 & 12085 \\
\hline Other Services & 1955 & 1731 \\
\hline 2. Transfers & 24284 & 11211 \\
\hline 3. Investment Income & -4921 & -1786 \\
\hline 4. Compensation of Employees & -589 & -265 \\
\hline Total & 42,655 & 23,458 \\
\hline
\end{tabular}

Furthermore, the Foreign Direct Investment (FDI) regime has been further liberalized and the World Investment Report 2006 mentions India as among the top 15 recipients of FDI with improved prospects for the intermediate run. 


\section{Illustrations of High Growth and Stagnation in the Indian Economy}

The broadening of the base for rapid growth in the Indian economy from service to include industry has meant that there has been rapid growth of incomes. Based on repeated surveys of consumer expenditure at the household level the NCAER has suggested that real incomes are expanding rapidly as Table 13 indicates.

Table 13: Growing Prosperity - All India

Income Figures in Rs. 000 per annum at 2001-02 prices, households in '000 numbers

\begin{tabular}{|l|c|c|c|c|}
\hline & $1995-96$ & $2001-02$ & $2005-06$ & $2009-10$ \\
\hline$<90$ & 131,176 & 135,378 & 132,249 & 114,394 \\
\hline $91-200$ & 28,901 & 41,262 & 53,276 & 75,304 \\
\hline $201-500$ & 3,881 & 9,034 & 13,183 & 22,268 \\
\hline $501-1,000$ & 651 & 1,712 & 3,212 & 6,173 \\
\hline $1,001-2,000$ & 189 & 546 & 1,122 & 2,373 \\
\hline $2,001-5,000$ & 63 & 201 & 454 & 1,037 \\
\hline $5,001-10,000$ & 11 & 40 & 103 & 255 \\
\hline $10,001+$ & 5 & 20 & 52 & 141 \\
\hline
\end{tabular}

Source: NCAER

The Indian middle class is not just growing at a rapid pace it has also become the segment driving consumer goods like cars and air-conditioners. While the middle class accounted for barely $5.7 \%$ of all Indian households in 2001-02, it already owned $60 \%$ of the airconditioners in the country and 25\% of all TVs, refrigerators and motorcycles. By 2009-10 the middle class is projected to account for $13 \%$ of the households. This will have a huge impact on the demand for consumer durables. NCAER predicts that the market for cars will grow at $20 \%$ a year, while bikes will clock growth of $16 \%$ per year

The projected consumption boom isn't just restricted to urban India. On the contrary, the NCAER survey suggests that the urban demand for some relatively low-end products will be saturated by the end of the decade, while rural demand picks up. As a result, the rural populace will own $80 \%$ of radios, $65 \%$ of CTVs, $48 \%$ of motorcycles, $40 \%$ of scooters and 2009-10. As the purchasing power in the villages goes up, the demand for cars too will rise by $11 \%$. The emergence of the middle class is a signal of maturity and is the most important stabilising force in the Indian economy. The $61^{\text {st }}$ Round of NSS conducted in 2005 shows a significant increase in aggregate rural household expenditure compared with a decade ago. This is reflected in higher penetration levels in rural households of almost all major items. Motorcycles are now owned by close to 8 per cent of rural households, compared with about 2 per cent 10 years ago. Over 25 per cent of rural households have TV sets, again about four times as many as a decade ago. Four per cent of rural households have refrigerators, while about 38 per cent have ceiling fans. These penetration levels too are several multiples of their 
magnitudes of a few years ago. There is, therefore, little question that rural households have begun to gain ground as far as the quality of life attributes goes. But, by any absolute standard, all these numbers underscore the huge distance that needs to be covered before even a simple majority of rural households possesses what are now considered necessities in an urban environment.

I now present some evidence of the performance of a high growth sector, automobiles, and the stagnation of another - agriculture. Table 14 records the rapid growth in production and exports of the automobile industry

Table 14: India: Automobile Production and Export

\begin{tabular}{|l|l|l|l|l|l|l|}
\hline \multicolumn{7}{|c|}{ Automobile Production (Numbers in 000) } \\
\hline & $2000-01$ & $2001-02$ & $2002-03$ & $2003-04$ & $2004-05$ & $2005-06$ \\
\hline Passenger Cars & 513 & 564 & 609 & 842 & 961 & 1046 \\
\hline Multi-utility vehicles & 128 & 106 & 112 & 146 & 249 & 263 \\
\hline Commercial vehicles & 157 & 163 & 204 & 275 & 350 & 391 \\
\hline Two wheelers & 3,759 & 4,271 & 5,076 & 5,625 & 6,527 & 7,600 \\
\hline Three wheelers & 203 & 213 & 277 & 341 & 374 & 434 \\
\hline Total & 4,759 & 5,316 & 6,280 & 7,229 & 8,461 & 9,735 \\
\hline Growth (per cent) & -2.00 & 11.70 & 18.60 & 15.12 & 16.80 & 14.97 \\
\hline & Automobile Export (Numbers in 000) & & \\
\hline Thre & $2000-01$ & $2001-02$ & $2002-03$ & $2003-04$ & $2004-05$ & $2005-06$ \\
\hline Total & 23 & 50 & 71 & 126 & 161 & 170 \\
\hline Growth (per cent) & 4 & 3 & 1 & 3 & 6 & 5 \\
\hline Multi-utility vehicles & 16 & 12 & 12 & 17 & 30 & 41 \\
\hline Commercial vehicles & 111 & 104 & 180 & 265 & 367 & 513 \\
\hline Two wheelers & 16 & 15 & 43 & 68 & 67 & 77 \\
\hline Three wheelers & 185 & 9.74 & 65.35 & 55.98 & 31.25 & 28.03 \\
\hline
\end{tabular}

Source: Economic Survey: Government of India 2006-07

The performance of agriculture, however, has been a matter of concern. Table 15 indicates average growth in area, production and yield under foodgrains, non foodgrains and all crops.

The contrast between the pre-reform and the post-reform periods in respect of the performance of agriculture is quite stark. Even of we define the pre-reform period to go as far back as the 1950s, when agricultural operations were subject to very high risks, except for the yield of non-foodgrains the performance in respect of rates of growth of area, production and yield was worse in the post reform period 1990-91 to 2004-05. Except for the growth of area under foodgrains performance during the 1980s was the best. The Green Revolution era was significant for Indian agriculture in more ways than one. 
Table 15: Average Growth rates of Area, Production and Yield under Foodgrains, Non-foodgrains and All Crops. (percentages)

\begin{tabular}{|l|c|c|c|c|c|c|c|c|c|}
\hline & \multicolumn{3}{|c|}{ Foodgrains } & \multicolumn{3}{c|}{ Non-foodgrains } & \multicolumn{3}{c|}{ All crops } \\
\cline { 2 - 9 } & Area & Production & Yield & Area & Production & Yield & Area & Production & Yield \\
\cline { 2 - 9 } 1950-51 to $1993-94$ & 0.53 & 2.99 & 2.03 & 1.51 & 3.33 & 1.30 & 0.81 & 3.05 & 1.72 \\
$1993-94$ to $2004-05$ & 0.30 & 1.44 & 0.90 & 0.34 & 2.63 & 1.49 & 0.33 & 1.72 & 1.11 \\
$1950-51$ to $1959-60$ & 1.64 & 2.79 & 0.99 & 2.06 & 3.13 & -0.25 & 1.91 & 2.81 & 0.56 \\
$1960-61$ to $1969-70$ & 0.63 & 2.96 & 2.01 & 0.97 & 3.08 & 1.35 & 0.71 & 2.96 & 1.71 \\
$1970-71$ to $1979-80$ & 0.19 & 1.38 & 0.53 & 0.75 & 1.78 & 0.98 & 0.32 & 1.44 & 0.65 \\
$1980-81$ to $1989-90$ & -0.02 & 3.33 & 2.88 & 1.10 & 3.89 & 2.24 & 0.24 & 3.45 & 2.57 \\
$1990-91$ to $1993-94$ & -0.80 & 2.03 & 2.00 & 2.40 & 3.18 & 1.20 & 0.08 & 2.45 & 1.65 \\
$1950-51$ to $1989-90$ & 0.61 & 2.61 & 1.60 & 1.22 & 2.97 & 1.08 & 0.79 & 2.66 & 1.37 \\
$1990-91$ to $2004-05$ & -0.07 & 1.64 & 1.27 & 1.03 & 2.81 & 1.39 & 0.25 & 1.96 & 1.29 \\
\hline
\end{tabular}

Source: Author's computation based on Reserve bank of India' Handbook of Statistics on the Indian Economy.

The stark conclusion about the near stagnation of productivity in Indian agriculture in the post reform period at the aggregate can be contrasted with the figures on yields reported for individual crops. Yields for major foodgrains grew faster in the 1980s than in the post reform period. The performance of some individual non-foodgrains has, however, been better in the post reform period. However, the performance of all non-foodgrains as a whole remains lacklustre.

One of the principal reasons for the stagnation of growth in agriculture has been the stagnation of agricultural investment. The performance of investment in Indian agriculture in comparison to investment in general is sketched in Figure 2 below.

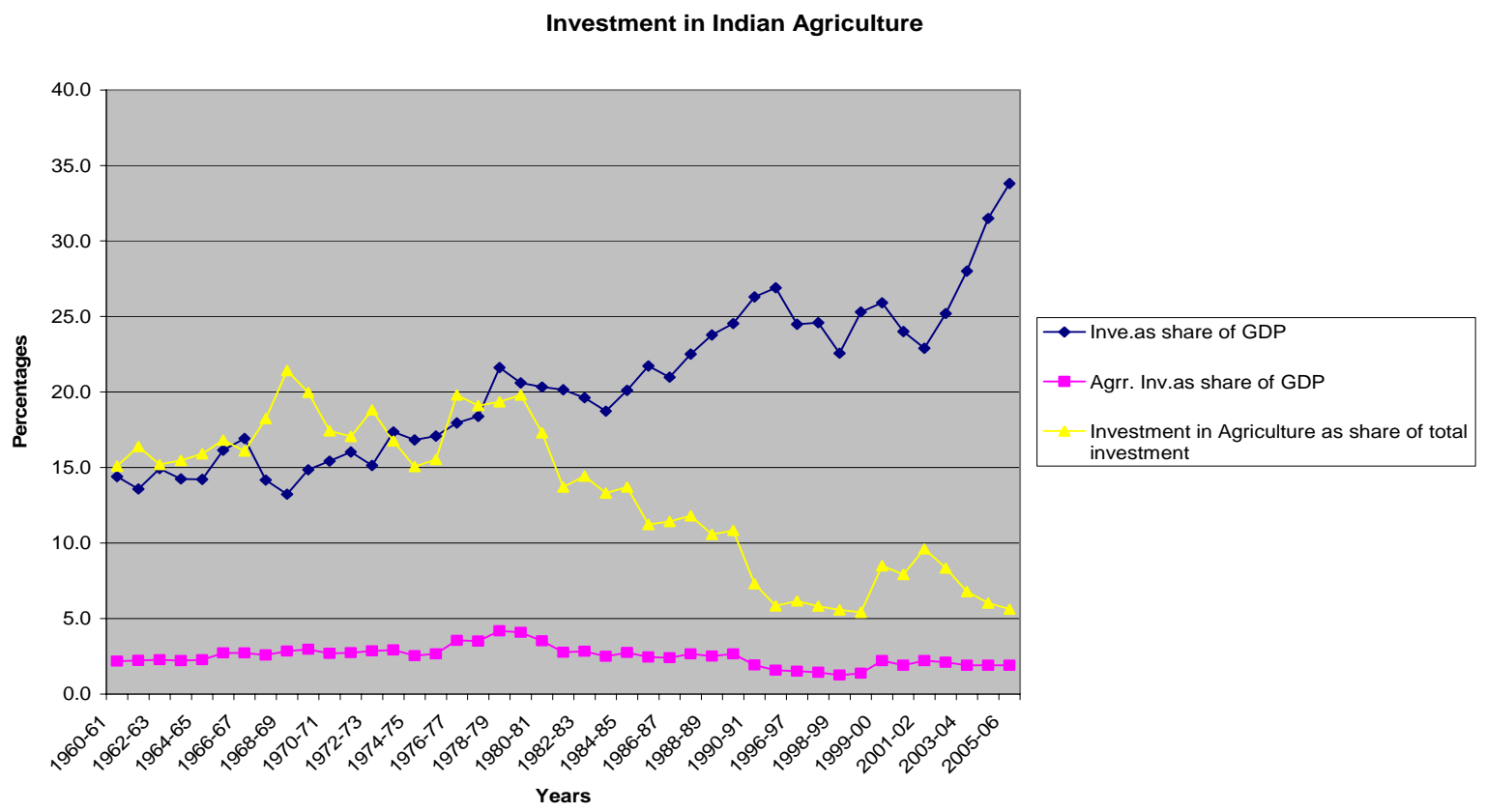

Figure 2: Investment in Indian Agriculture

Source: Computed from Figures provided by Reserve Bank of India 
As Figure 2 shows whereas investment as a proportion of GDP has been on a rising trend since the 1970s agricultural investment as a share of total investment has been falling since the 1980s. There was a mild revival between 1999-00 and 2002-03 but, since then, agricultural investment as a proportion of GDP has resumed its downward trend. This is in sharp contrast to the spurt in aggregate investment since 1999-00. Agricultural investment as a proportion of GDP has also been falling.

However, whereas investment in agriculture has been stagnant the subsidy for agriculture has risen sharply (Figure 3).

Agricutural Subsidies at 2000-01 Prices (Rs. billion)

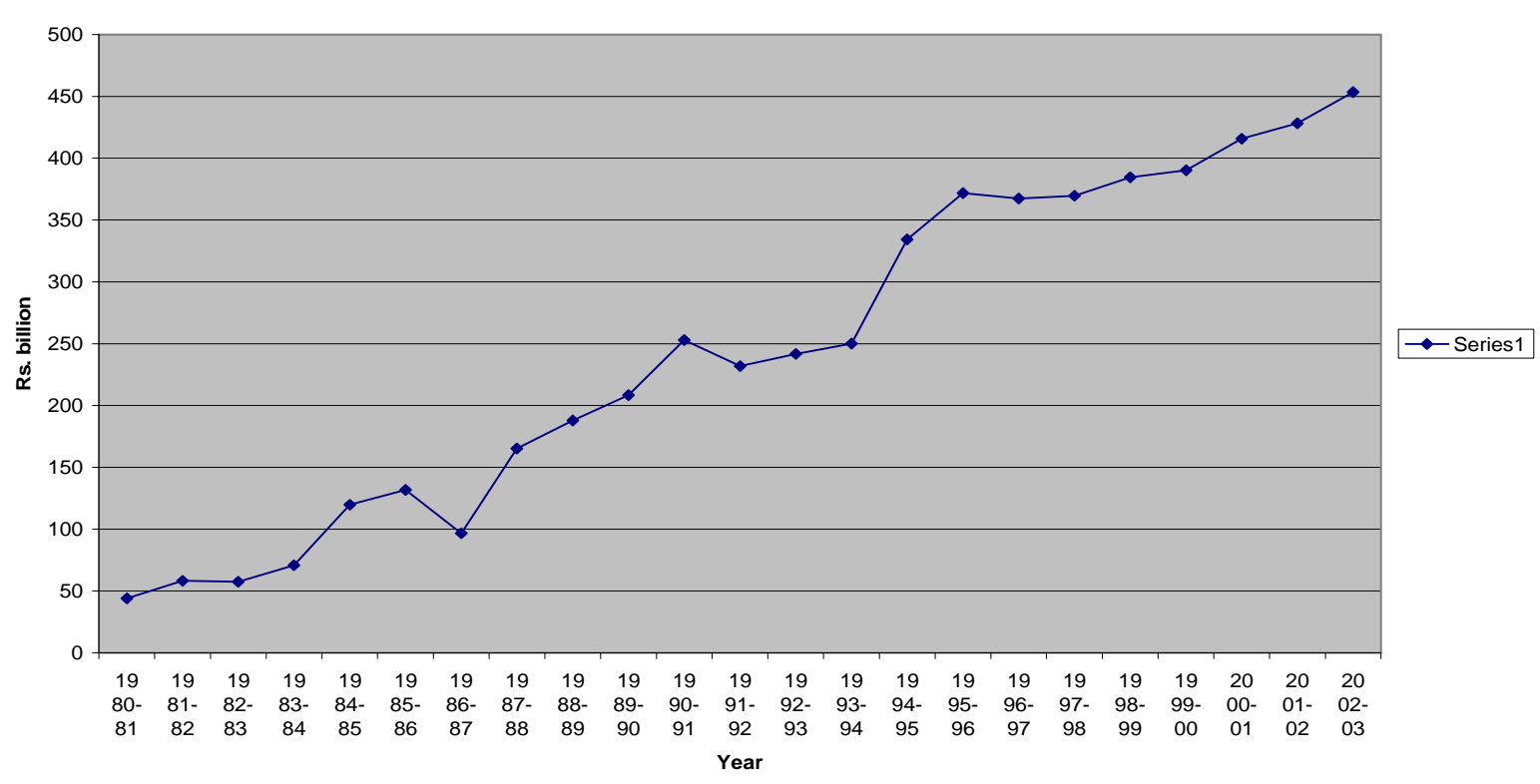

Figure 3: Agricultural Subsidies in India at 2000-01 prices (Rs. Billion)

Source: Computed from Mullen et al. (2005)

\section{Emerging Constraints on Rapid Economic Growth in India}

Although India's economic growth record has been truly impressive the country does not perform as well on a broader set of human development indicators. India's Human Development Indicator (HDI) score, for example, improved only marginally from 0.302 in 1981 to 0.381 in 1991 and 0.472 in 2001. India's HDI rank in 2002 was $124^{\text {th }}$ - which was a deterioration on the rank (of $115^{\text {th }}$ ) attained in the previous year. In 2003 there was further slippage and India was $127^{\text {th }}$ in the global ranking. In the 2005 Human Development Report this ranking was maintained whereas in 2006 India improved its ranking marginally to $126^{\text {th }}$.

Some of these shortcomings have transformed themselves into constraints on rapid economic growth in India. Evolution of the Indian economy according to the sanguine aggregate picture sketched above is subject to how these constraints to rapid economic growth in India work themselves out. We classify these constraints in four categories: (i) increasing spatial inequality; (ii) stagnating employment; (iii) high fiscal deficit; and (iv) inadequate growth of infrastructure. These constraints often reinforce each other - particularly through the democratic political process. I now discuss these in turn. 
Table 16: Mean and Standard Deviation of Growth Rates of fifteen major Indian states

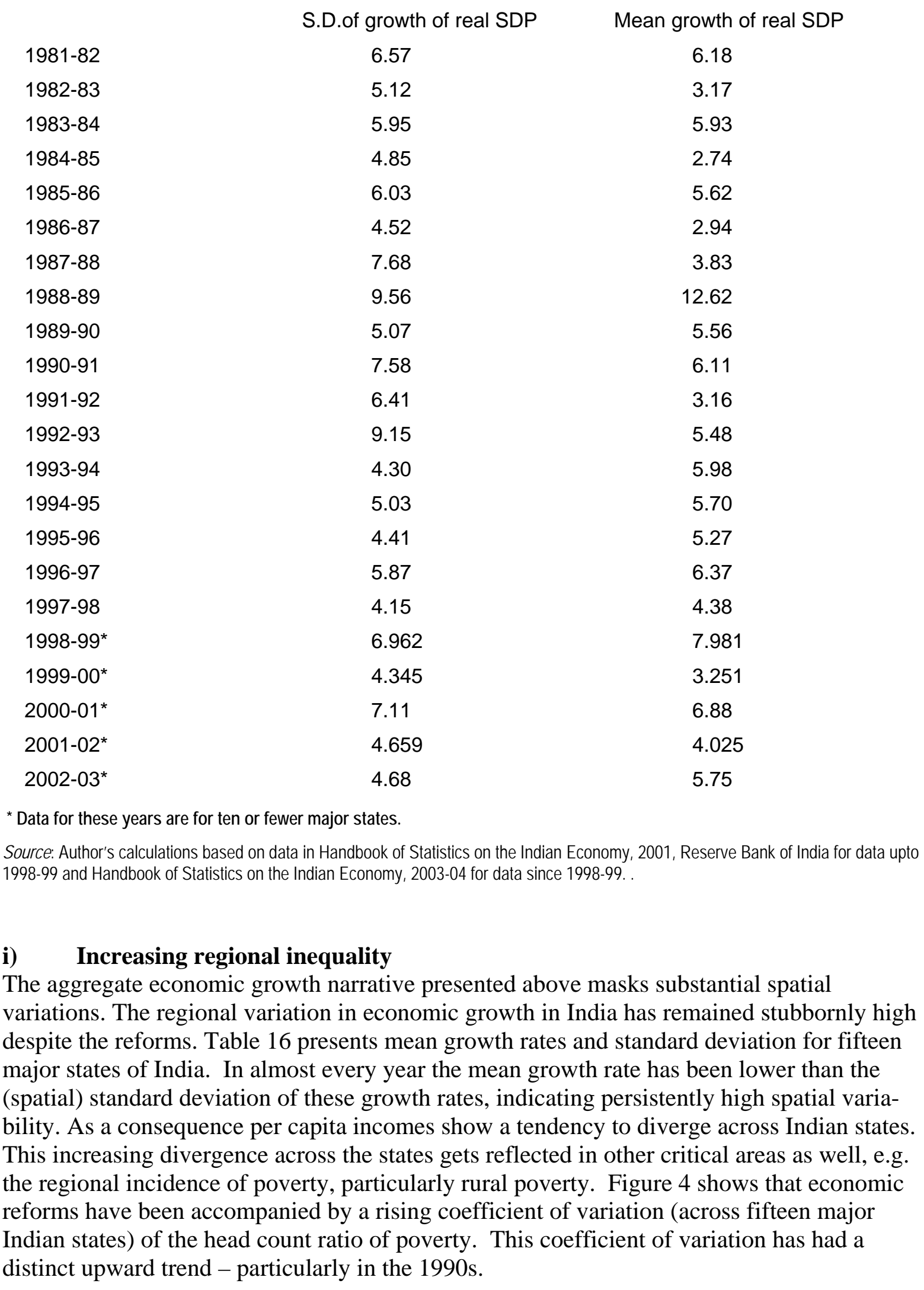


Figure 4: Coefficients of Variation of Head Count Ratios in the Rural, Urban and Aggregte Sectors

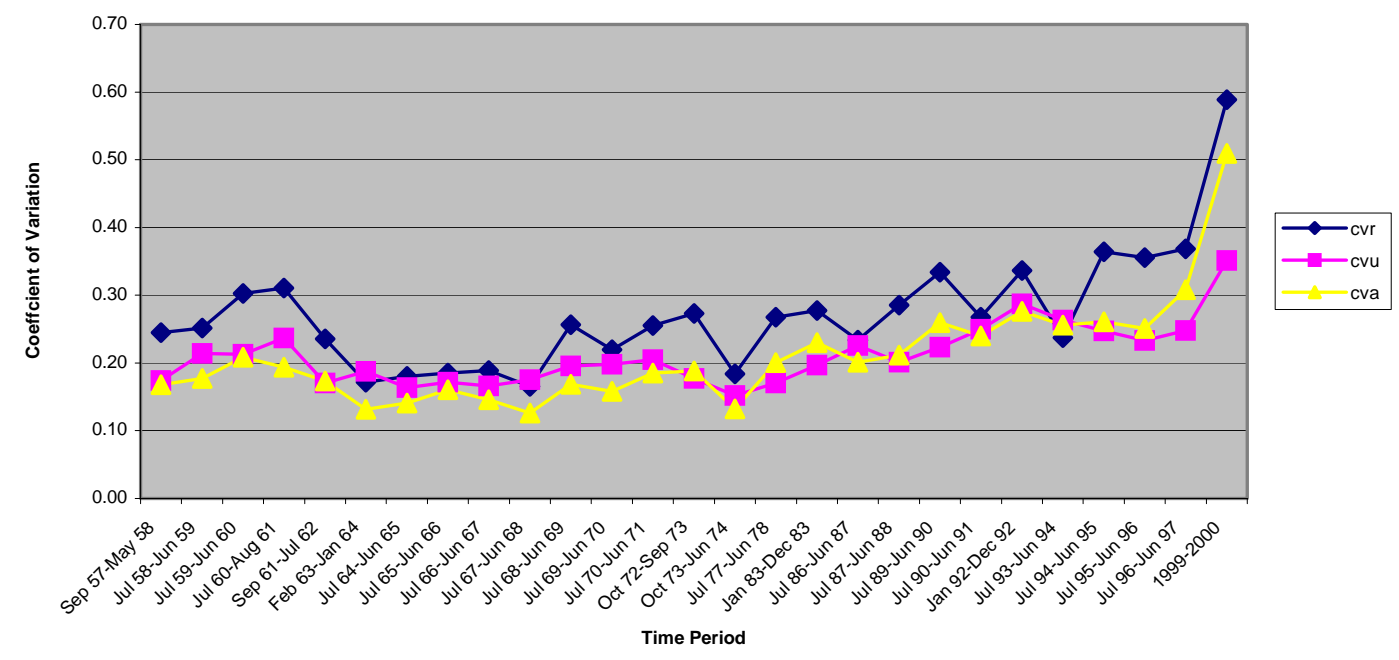

Note: $\quad c v r=$ coefficient of variation of rural Head Count ratio,

$\mathrm{cvu}=$ coefficient of variation of urban Head Count ratio;

$\mathrm{cva}=$ coefficient of variation of aggregate Head Count ratio.

Source: Jha (2001)

Jha (2001) shows that there is lack of convergence (in a formal statistical sense) in the incidence of rural poverty across Indian states both in terms of their ranks with respect to poverty as well as in terms of their levels of poverty. In fact in respect of the critical magnitudes of poverty, mean consumption and inequality of consumption, economic reforms do not seem to have made much difference to the inequality across Indian states for any category except urban mean consumption. This lack of convergence extends itself to the level of NSS agro-climatic zones (NSS regions) ${ }^{5}$ as Jha and Sharma (2003) point out. Further, as Jha (2004) has shown, there has been some increase of personal inequality in India as a consequence of the economic reforms program.

To further investigate the increasing concentration of the poor in India I identify five states with the highest number of expenditure poor in 1987-88 and follow the progress of these states over time. Data pertaining to the rural sector from the last three quinquennial rounds of

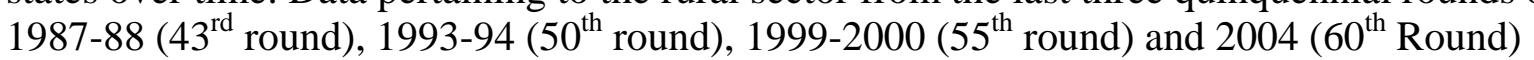
are used. All results (reported in Table 17) refer to the rural sectors of these states and the national economy. Also noted (within parentheses) are the shares of the rural sectors of these states in national rural population, reckoned according to the sizes of the NSS sample originating from these states: in 1987-88 UP had 12.81 per cent of the national rural population and 14.99 per cent of the total rural poor.

\footnotetext{
${ }^{5}$ A National Sample Survey (NSS) region has a certain agro-climatic homogeneity within it. Small states such as Tripura constitute one region whereas larger states such as Uttar Pradesh are made up of more than one such region. States may not be a good unit of analysis in a regionally diversified country such as India. Even within the states there is considerable heterogeneity - coastal Maharashtra versus interior Maharashtra, Eastern vs. Western Madhya Pradesh etc. In the area of poverty incidence, for example, only Orissa and a few other states are such that there is a clear-cut congruence between high incidence of poverty and state geographical boundaries.
} 
Table 17: Distribution of the Burden of Deprivation in Rural India

\begin{tabular}{|c|c|c|c|c|c|c|c|c|}
\hline \multirow[t]{2}{*}{ State } & \multicolumn{2}{|c|}{$43^{\text {rd }}$ round (1987-88) } & \multicolumn{2}{|c|}{$50^{\text {th }}$ round (1993-94) } & \multicolumn{2}{|c|}{$55^{\text {th }}$ round $(1999-2000)$} & \multicolumn{2}{|c|}{$60^{\text {th }}$ Round $2004^{*}$} \\
\hline & $\begin{array}{l}\text { per cent of } \\
\text { national total } \\
\text { of expenditure- } \\
\text { poor } \\
\text { (\% of national } \\
\text { population) }\end{array}$ & $\begin{array}{l}\text { Rank in } \\
\text { terms of } \\
\text { number } \\
\text { deprived } \\
\text { 1987-88 }\end{array}$ & $\begin{array}{l}\text { per cent of } \\
\text { national total } \\
\text { of expenditure- } \\
\text { poor } \\
\text { (\% of national } \\
\text { population) }\end{array}$ & $\begin{array}{l}\text { Rank in } \\
\text { terms of } \\
\text { number } \\
\text { deprived } \\
\text { 1993-94 }\end{array}$ & $\begin{array}{l}\text { per cent of } \\
\text { national total } \\
\text { of expenditure- } \\
\text { poor } \\
\text { (\% of national } \\
\text { population) }\end{array}$ & $\begin{array}{l}\text { Rank in } \\
\text { terms of } \\
\text { number } \\
\text { deprived } \\
\text { 1999-2000 }\end{array}$ & $\begin{array}{l}\text { per cent of } \\
\text { national total } \\
\text { of expenditure- } \\
\text { poor } \\
\text { (\% of national } \\
\text { population) }\end{array}$ & $\begin{array}{l}\text { Rank in } \\
\text { terms of } \\
\text { number } \\
\text { deprived } \\
2004\end{array}$ \\
\hline UP & 14.99 (12.81) & 1 & $15.28(13.1)$ & 2 & $15.2(13.4)$ & 2 & $17.3(14.4)$ & 1 \\
\hline Bihar & $13.25(9.63)$ & 2 & $17.35(10.1)$ & 1 & $18.51(10.5)$ & 1 & $15.6(9.0)$ & 2 \\
\hline MP & $11.23(7.83)$ & 3 & $11.36(7.83)$ & 3 & $13.46(7.4)$ & 3 & $11.7(7.3)$ & 3 \\
\hline $\begin{array}{l}\text { Andhra } \\
\text { Pradesh }\end{array}$ & $8.14(7.43)$ & 4 & 7.08 (7.11) & 6 & $8.14(7.47)$ & 5 & $9.5(7.4)$ & 4 \\
\hline Maharashtra & $7.86(7.03)$ & 5 & $8.16(6.5)$ & 5 & $6.02(5.91)$ & 7 & $5.8(7.7)$ & 6 \\
\hline $\begin{array}{l}\text { Total of the } \\
\text { five states }\end{array}$ & $55.47(44.73)$ & & $59.23(44.64)$ & & $61.35(44.66)$ & & $59.9(45.8)$ & \\
\hline
\end{tabular}

* To make the data comparable across rounds UP and Uttarakhand, Bihar and Jharkhand, and MP and Chattisgargh were each lumped together. The new states of Uttarakhand, Jharkhand and Chattisgarh were formed by splitting UP, Bihar and MP, respectively, in 2000.

Source: Jha, Gaiha and Sharma (2006) and Author's calculations based on National Sample Survey Data.

The single most important conclusions to be drawn from this table is that the shares of the chosen five states in the number of deprived increased steadily over time even though their share of national rural population remained almost constant. The combined share of UP, Bihar, MP, Andhra Pradesh and Maharashtra in the national expenditure-poor figure was 55.47 per cent in 1987-88. This increased to 59.23 per cent in 1993-94, to 61.35 per cent in 1999-2000 and remained almost unchanged at 59.99 per cent in 2004. However, the combined share of these five states in national rural population was almost steady at slightly above 44.6 per cent. Almost half of the MPs elected to the lower House of the Indian Parliament come from these five states.

The increasing concentration of deprivation has created a situation in which the poor are ill placed to take advantage of new opportunities created by economic reforms just as they may suffer less from the loss of old opportunities in sectors that were artificially protected prior to reforms. Thus the poor do not have much stake in the success of the economic reforms program. In a democratic country such as India, this means that political parties espousing pro-reform policies may not necessarily win elections. This could emerge as a significant constraint on rapid economic growth in India.

Results on rural poverty for the latest round of the NSS ( $60^{\text {th }}$ Round are reported in Table 18). Summary information on the variation of such poverty across the country is reported in Table 19. The decline in poverty has been modest, even though mean consumption is quite high now and the dispersions of the poverty across states and NSS regions have grown. 
Table 18: Mean Consumption, Poverty and Inequality in Rural India at the National Level (Poverty Line Rs. 399 per capita per month)

\begin{tabular}{|l|c|c|c|}
\hline & 30 -Day recall & 7-day recall & Combined \\
\hline $\begin{array}{l}\text { Mean per capita consumption } \\
\text { (Rs. Per month) }\end{array}$ & 786 & 852 & 818 \\
\hline PG0 I & 22.90292 & 17.9421 & 20.62485 \\
\hline PG1 & 0.045277 & 0.034262 & 0.040367 \\
\hline PG2 & 0.01378 & 0.010126 & 0.012199 \\
\hline Gini Coefficient) & 36 & 37 & 37 \\
\hline
\end{tabular}

Source: Jha et al. (2006)

Table 19: Variation of Mean Consumption, Poverty and Inequality across 20 States and 63 Constituent NSS regions in India

\begin{tabular}{|c|c|c|c|c|c|c|c|c|}
\hline & Average & Highest & Lowest & $\begin{array}{c}\text { Coefficient } \\
\text { of variation } \\
\text { (standard } \\
\text { deviation) } \\
\text { /mean }\end{array}$ & Average & Highest & Lowest & $\begin{array}{c}\text { Coefficient } \\
\text { of variation } \\
\text { (standard } \\
\text { deviation) } \\
\text { /mean }\end{array}$ \\
\hline & \multicolumn{4}{|c|}{20 States } & \multicolumn{4}{|c|}{63 NSS regions } \\
\hline $\begin{array}{l}\text { Mean consumption } \\
\text { (Rs. per capita } \\
\text { per month) }\end{array}$ & 802.64 & 1220.35 & 507.98 & 0.24 & 758.91 & 1504.58 & 382.32 & 0.304099 \\
\hline PG0 & 18.25 & 48.97 & 1.43 & 0.70 & 21.84 & 71.98 & 0 & 0.668 \\
\hline PG1 & 0.035 & 0.121 & 0.001 & 0.84 & 0.0433 & 0.2278 & 0 & 0.945 \\
\hline PG2 & 0.0107 & 0.042 & $9.41 \mathrm{E}-05$ & 0.95 & 0.0069 & 0.015079 & 0 & 0.7406 \\
\hline Gini Coefficient & 0.314 & 0.398 & 0.197 & 0.171 & 0.2997 & 0.4628 & 0.11239 & 0.194 \\
\hline
\end{tabular}

N.B. Variations across the 20 states and 63 NSS regions constituting these states studied are recorded here. Thus the averages here need not tally with those for the country as a whole.

Source: Jha et al. (2006)

\section{(ii) Rising Unemployment}

An additional emerging constraint on rapid economic growth in India is the inability - at least so far - of the reforms to generate a sufficient number of jobs. India has long had problems with unemployment and underemployment. However, economic growth in the pre-reform period did impact on unemployment by raising the demand for labour. The employment elasticity of output growth was high. But, one of the characteristics of post-reform economic growth in India has been the relatively sluggish growth of employment even in the face of buoyant output growth. (Table 20)

\footnotetext{
${ }^{6}$ This and other mean consumption magnitudes are weighted means of expenditures.
} 
Table 20: Unemployment in India, Current Daily Status Basis (percentages)

\begin{tabular}{|c|c|c|c|c|c|c|}
\hline & \multicolumn{2}{|c|}{ 1993-94 } & \multicolumn{2}{|c|}{ 1999-00 } & \multicolumn{2}{|c|}{2004} \\
\hline & Rural & Urban & Rural & Urban & Rural & Urban \\
\hline Male & 5.6 & 6.7 & \multirow{2}{*}{7.21} & \multirow{2}{*}{7.65} & 9.0 & 8.1 \\
\hline Female & 5.6 & 10.5 & & & 9.3 & 11.7 \\
\hline
\end{tabular}

Source: Economic Survey, Government of India, 2006-07

The NREGA will provide at best only 100 days of employment per household for the 200 poorest rural districts at the minimum wage which is, at best, a band-aid solution for those most in need and cannot be construed as a secular increase in the demand for labour which, alone, can make a serious dent on the scourge of rising unemployment in India..

In addition to open unemployment there also exists India's persistent problem of underemployment. Underemployment in various segments of the labour force is quite high. The estimates of the $50^{\text {th }}$ Round of the NSS indicate that although open unemployment was only 2 per cent in 1993-94 on US basis, the incidence of under-employment and unemployment taken together was as much as 10 per cent that year. This occurred despite the fact that the incidence of underemployment was reduced substantially in the decade ending 1993-94.

The higher unemployment creates a political climate in which policy measures such as increased liberalization of international trade become increasingly difficult to take since such policies may be construed to involve short-term increases in unemployment or, at the least, increase the perceived uncertainty of tenure of employment. In fact since liberalization policies might entail greater vulnerability to external risk, there might well be pressures for governments to increase employment in the public sector (Rodrik, 1998). This might well bloat up the size of an inefficient public sector and reduce the effectiveness of any economic reforms program.

\section{(iii) High Fiscal Deficit}

India's fiscal deficit woes have been well documented (see, for instance, Jha, Chand and Sharma, 2003). The combined fiscal deficit of the central and state governments has been hovering near 10 percent of GDP for quite some time now but has come down in the recent past. This figure was 9.6 percent in 2002-03, 8.5 percent in 2003-04, 8.4 per cent in 2004-05 and is estimated to be 7.5 per cent in 2005-06. Although there is a distinct improvement in the fiscal deficit scenario the public debt of India has been climbing steadily and is currently reported at about 85 percent of GDP. There has been a change in the composition of this debt, however, with the share of external debt falling and that of internal debt rising.

This persistently high fiscal deficit has had deleterious effects. It has reduced the amount of resources available for investment by lowering public saving. In addition, public dissaving because of the high fiscal deficit is reducing the resources available for investment (Saggar, 2003). Since 1998-99 the public sector has been dissaving continuously. Furthermore, some of the savings-investment gap spills over onto the external balance. In addition, persistent pre-occupation with controlling the fiscal deficit reduces the flexibility to conduct countercyclical fiscal policy. 
Budgetary deficits - directly measured - are only part of the fiscal burden of the state in India. It is well-known that contingent liabilities of the government are very large. In the past the government has had to bail out insolvent banks and other financial institutions (the latest being the Unit Trust of India) at severe cost (Sharma, 2004).

\section{(iv) Problems of Infrastructure}

India's record in providing high quality, reliable and reasonably priced infrastructural services to its households and businesses has been inadequate. There is sufficient evidence to suggest that this state of affairs will continue for some time. Even though the potential of the private sector to meet India's pressing infrastructure needs is largely untapped, and hence can be expanded considerably, there will continue to be a major role for the public sector in providing infrastructural services, particularly in the less developed regions/states of India. India's infrastructure requirements have been put by one estimate at US\$215 billion in the 2001 to 2006 period. $^{7}$

However, before such investment can take place, the paucity of infrastructural facilities hampers rapid economic growth. Jha and Thapa (2003) document that states with poor infrastructure have poor records of poverty reduction. Further, there is clear linkage between agricultural productivity and agricultural infrastructure. Jha and Thapa (2003) also document the links between poor pricing of electricity and aggravated distortions in its usage as well as huge losses in transmission and distribution.

The upshot of these arguments is that there are important constraints to rapid economic growth in India. Whereas high levels of the fiscal deficit and public debt reduce resources available for investment, poor infrastructure facilities reinforce the tendency toward increasing concentration of poverty. The fact that some of the poorest regions in the country have poor economic reform and governance records as well as some of the highest population densities and thus have high representation in Parliament indicates that reform measures that do not appear to be beneficial in the short run have little political support. The fact that unemployment has actually increased during the period 1993-94 to 2004 is further indication of the lack of popular support for rapid liberalization and reform.

\section{Prospects for alleviating the constraints on rapid economic growth}

That rapid economic liberalization of the form that took place in China beginning in the late 1970s is difficult to achieve in India is now clear. In a democratic society tolerance for rapidly increasing inequality and slow realization of gains of liberalization for the poor is low. For instance, India will not be able to countenance the vast regional inequality that has emerged in China between the coastal areas and the interior. Hence, relieving the constraints on building consensus for rapid liberalization is an essential part of the strategy to sustain rapid economic growth in India.

How likely is this? Although there exists room for reorienting subsidies it is difficult to see how their total magnitude can be reduced significantly. Some expenditures are highly inflexible and three such items (interest payments, defence expenditure and subsidies) make up almost 100 percent of tax revenues. India's expenditure/GDP ratio is not much out of line for developing countries and is substantially below that of OECD countries.

\footnotetext{
${ }^{7}$ Estimates by the Expert Group on the Commercialization of Infrastructure Projects reported in NCAER (1996).
} 
However, there is much to be gained from tax reform and substantial opportunity exists for raising the tax/GDP ratio. This ratio has been stagnant for some time now and is substantially below that of OECD and even some developing countries. Jha, Chand and Sharma (2003) discuss the contours of a tax reform program to raise the tax/GDP ratio. This involves expanding the tax net by removing exemptions and taxing services as well as agricultural income, consolidating and rationalizing indirect taxes into a value added tax and improving tax administration.

Such tax reform and lowering the fiscal deficit becomes even more necessary because of the extent of contingent liabilities of the government. These include but are not confined to the non-performing assets of banks.

Taking efforts to increase the employment elasticity of income growth is another important challenge facing Indian policymakers. Rapid rise in agricultural employment must await substantial investment - particularly in agricultural infrastructure. Employment growth in the services sector has been impressive but the capacity of this sector to absorb labour is limited. For purposes of employment expansion India will have to rediscover its latent comparative advantage in low value added manufacturing. This has been the area of most rapid growth in China and several Southeast Asian countries. India did not enter this club and imposed high tariffs on these products while at the same time producing these product domestically in "small scale industries", many of which were granted reservations for producing specific goods. The result has been high cost production which is non-competitive both in the domestic and international markets.

A more enlightened policy would be to remove the reservations for the small scale industrial sectors as well as reducing tariffs. Labour market regulations can be made more flexible. After decades of high GDP growth China and Southeast Asia have moved up the value chain in manufacturing production and India could well occupy the vacated low value added manufacturing space. Indeed India could become one of the most important production centres in these areas. This also has the potential to create large increases in employment.

Improvements in policy towards infrastructure have been suggested in a number of documents (see for example, India Infrastructure Report 2002, World Bank 2004). India is slowly moving in the direction of introducing competitive markets in infrastructure, with private sector production under modern regulatory structures. As a consequence some progress has been made in the areas of telecom, roads, ports, electricity and aviation. But much remains to be done. For example, in the area of electricity, the big change is the Electricity Act, which has mooted the idea of a pro-competitive framework whereby producers and consumers of electricity can interact in an unfettered market. However, after the 2004 Parliamentary elections the new government has already announced that the implementation of the Electricity Act would be delayed by a year. In the meantime, a number of states have reverted to the practice of providing free electricity to farmers. Thus progress on this front has been slow and there have been some retrograde steps as well.

The one area in which considerable progress can be expected is telecom. Mobile telephone and associated technology has grown rapidly in India. India has in excess of 50 million mobile phones with a rate of growth of 2 million phones a month. Internet access has improved considerably and there are plans to bridge the rural-urban divide in internet connectivity by rapid expansion of services in rural areas. 
Some progress has also been achieved in the areas of roads. There is a substantial project to build new highways - including the so-called "golden quadrilateral" to connect the four major cities of New Delhi, Mumbai, Kolkata and Chennai with six lane expressways and supplementary feeder routes. Such programs will enable more rapid transport of goods and services between vast distances and enable firms separated by such distances to trade with each other directly.

The functioning of ports has also recorded some improvements - partly as a result of contracting out the operations of ports to international firms with specialised expertise on this subject. According to Kelkar (2004) the turnaround time at ports dropped by half, from 7.5 days in 1996-97 to 3.5 days in 2001-02. India currently has 12 major ports and 185 minor /intermediate ports spread across the vast coastline of $7517 \mathrm{kms}$. They handle almost 90 per cent of India's total foreign trade with the 12 major ports alone handling about 75 per cent. In recent times there has been rapid, even accelerating, growth in India's port traffic - as high as 9.9 per cent in 2003-04. In 2004-05 Indian ports handled cargo of 510 million tonnes, an increase of 10.8 per cent over 2003-04. India is seeking to double port capacity in the near term and has also embarked on an ambitious program to developfeeder roads to port facilities. Airport privatisation is back on the agenda after a certain delay.

Thus the prospects for effective alleviation of the constraints facing higher economic growth are mixed but, on balance, they appear positive. However, India must continue to adopt a forward looking economic reforms program to work around some of these constraints and ensure high and stable growth can be put in place.

\section{Conclusions}

After two decades of economic reforms the Indian economy is at a crossroads. The reforms program has yielded considerable returns in the form of higher and more stable growth as well as considerable modernization of the economy. After more than two decades of impressive economic growth and some important reforms as well as deregulation, the Indian economy is at the threshold of even higher growth.

But, unforeseen and stubborn challenges have been thrown up especially in the areas of the high fiscal deficit and financial sector weakness, increasing regional and personal inequality, low elasticity of employment with respect to growth and inadequate infrastructure. Several of these, e.g., inadequate decline in poverty are such that they can be addressed best by high and sustained economic growth. Thus the relation between economic growth and economic reforms is non-linear. The Indian economy needs to undergo further economic reforms in order to fully realise its potential of economic growth. But, there might be short-term constraints on economic reforms especially when they play themselves out through the democratic process. This is an important challenge for policymaking in India. 


\section{References:}

Bosworth, B. and S. Collins (2007) “Accounting for Growth: Comparing China and India” NBER Working Paper no. 12943, Cambridge, Massachusetts.

Clydesdale, G. (2007) "What Happened to Indian Prosperity? The Systemic Loss of Prosperity” Journal of the Asia Pacific Economy, vol.12, no.3, pp. 305-328.

Government of India, Finance Commission (1994) Report of the Tenth Finance Commission, New Delhi.

India Infrastructure Report (2002), 3i Network, New Delhi: Oxford University Press.

Jha, R. (2001) Economic Reforms, Economic Growth and Anti-Poverty Strategy in India, Country Strategic Opportunities Paper, International Fund for Agricultural Development, Rome, 2001

Jha, R. and A. Sharma (2003) "The Spatial Distribution of Rural Poverty in the last three Quinquennial Rounds of the NSS, Economic and Political Weekly, vol. 38, no.47, pp. 4985-4993.

Jha, R., Chand, S. and A. Sharma (2003) “The Fiscal Constraint on India’s Economic Growth” in R. Jha (ed.) Indian Economic Reforms, Basingstoke, Houndmills, Palgrave Macmillan.

Jha, R. and P. Thapa (2003) “India's Infrastructure Sector” in R. Jha (ed.) Indian Economic Reforms, Basingstoke, Houndmills, Palgrave Macmillan.

Jha, R. (2004) “Reducing Poverty and Inequality in India: Has Liberalization Helped?” in Cornia, G.A. (ed.) Inequality, Growth and Poverty in an ear of Liberalization” Oxford, U.K. and New York: Oxford University Press.

Kelkar, V. (2004) “India: On the Growth Turnpike” 2004 Narayanan Oration, Australia South Asia Research Centre, Australian National University.

Jha, R., Gaiha, R. and A. Sharma (2006) "Mean Consumption, Poverty and Inequality in Rural India in the Sixtieth Round of the National Sample Survey” ASARC Working Paper 2006/11, Australian National University.

Maddison, A. (2006) The World Economy, OECD: Paris, Development Centre Studies

Mullen, K., Orden, D. and A. Gulati (2005) “Agricultural Policies in India: Producer Support Estiamtes 19852002” MTID Discussion Paper No. 82, IFPRI, Washington D.C.

National Council of Applied Economic Research (NCAER) (1996) The India Infrastructure Report, Expert Group on the Commercialization of Infrastructure Projects, New Delhi.

Nurkse, R. (1953) Problems of Capital Formation in Underdeveloped Countries, Oxford: Blackwell

Reserve Bank of India (2004) “Macroeconomic and Monetary Developments in 2003-04”, Annual Policy Statement for 2004-05.

Rodrik, D. (1998) “Why do More Open Economies have Larger Governments?” Journal of Political Economy, 106(6), pp.997-1032.

Rodrik, D. and A. Subramanian (2004) “From 'Hindu Growth’ to Productivity Surge: The Mystery of the Indian Growth Transition” International Monetary Fund Discussion Paper, WP/04/77.

Saggar, M. (2003) “A Perspective on Saving, Investment and Macroeconomic Policies in India” in R. Jha (ed.) Indian Economic Reforms, Basingstoke, Houndmills, Palgrave Macmillan.

Sharma, A. (2004) Fiscal Deficits, Banking Crisis and Adjustment in a semi-open Economy, unpublished Ph.D. dissertation, Australian National University.

Tagore, R. (1941) “Crisis in Civilization”available at http://www.vbharat.ernet.in/html/crisis_in_civilization.html Bengali version Sabhyatar Sankat, Rabindra Rachanavali vol.26, Calcutta: Vishwabharati.

Thirlwell, M. (2004) “India- the next economic giant” Lowy Institute, Sydney.

World Bank (2000) India: Country Framework Report for the Private Participation In Infrastructure, World Bank/Public-Private Infrastructure Facility, Washington, D.C. 